\title{
The role of text characteristics in the reading comprehension of primary school children in Spanish
}

\author{
Carla Míguez-Álvarez ${ }^{*}$, Miguel Cuevas-Alonso', Ángeles Saavedra² \& Ramón G. Cabanach ${ }^{3}$ \\ 'Departamento de Lengua Española, Universidade de Vigo \\ ${ }^{2}$ Departamento de Estadística e Investigación Operativa, Universidade de Vigo \\ ${ }^{3}$ Investigación Operativa
}

- Recibido: 26 - 11 - 2021 . Aceptado: 10 - 01 - 2022

ABSTRACT. During the early grades of primary school, texts are mainly narrative and focus on technical aspects such as decoding words and understanding simple syntax. However, from 4th grade onwards, texts become increasingly more difficult and expository texts become the main source of knowledge from which children will have to extract and learn new information while creating their mental model. This article examined the influences of two main text characteristics: text genre and level of representation (text base and mental model), in the reading comprehension scores of 313 Spanish primary school children aged 8 to 11 to study the relationship between these variables as well as the differences between grades. Comprehension of each text genre was assessed through a validated multiple-choice questionnaire and each variable was compared through a series of correlational methods, such as Pearson's correlation, Spearman's rho and ANOVAs. The results showed that all grades obtained significant higher scores on the text base than the mental model but only the expository texts exhibited better results when passing from $4^{\text {th }}$ to $5^{\text {th }}$ and $6^{\text {th }}$ grade. This study provides findings that may contribute to the topic of literacy education during primary school.

KEYWORDS: Expository text; Narrative text; Mental model; Primary education; Reading development.

El papel de las características textuales en la comprensión lectora de alumnado de Educación Primaria en lengua española

RESUMEN. Durante los primeros cursos de primaria, los textos son principalmente narrativos y se centran en aspectos técnicos como la decodificación y la comprensión de sintaxis simple. Sin embargo, a partir de $4^{\circ}$ curso, los textos se vuelven cada vez más difíciles y los expositivos se convierten en la principal fuente de conocimiento a partir de la cual los estudiantes tendrán que extraer y aprender nueva información mientras crean su modelo mental. El presente artículo se centra en examinar las influencias de dos características principales de cualquier texto: el género textual y el nivel de representación (base textual y modelo mental) en las puntuaciones obtenidas en las pruebas de comprensión lectora de 313 estudiantes españoles de educación primaria con edades entre 8 y 11 años para averiguar la relación existente entre estas variables, así como las diferencias entre cursos. La comprensión de cada género textual se evaluó mediante un cuestionario de opción múltiple y cada variable se comparó mediante una serie de métodos correlacionales (correlación de Pearson, rho de Spearman y ANOVAs). Los resultados muestran que todos los cursos obtuvieron puntuaciones significativamente más altas en la base textual que en el modelo mental, pero solo se apreciaron mejores resultados con el paso de $4^{\circ}$ a $5^{\circ}$ y $6^{\circ}$ curso en los textos expositivos. Los hallazgos de este estudio suponen una contribución relevante para la alfabetización en la educación primaria.

PALABRAS CLAVE: Texto expositivo, Texto narrativo, Modelo mental, Educación primaria, Desarrollo lector.

\author{
*Correspondencia: Carla Míguez-Álvarez \\ Departamento de Lengua Española, Universidade de Vigo \\ Dirección: 36310, Vigo, España. \\ E-mail: camiguez@uvigo.es
}

In the present society that we live in, it is essential to know, understand and produce any type of written form. In fact, difficulties with reading, specifically with reading comprehension, at a young age can cause difficulties at academic, professional and even personal levels that can 
stay throughout adolescence and adulthood and have an impact on the well-being of the person if no remedial action is taken from the earliest stages (Brockmeier \& Olson, 2009; Eloranta et al., 2019; Lonigan, 2007).

Reading is a very complex process due to the high amount of levels, abilities and components that the reader must master (Graesser, 2007). Due to the fact that reading is not an inherent ability and must be acquired through a formal and continuous training, in order to read any type of text, children must use a series of unconscious and automated brain mechanisms that were previously used in other activities. These abilities range from the most basic ones, such as decoding and understanding explicit text, to more complex tasks, such as inference making and the creation of a mental model or implicit representation of the text (Yildrim et al., 2020).

Therefore, in order to comprehend any type of text, the reader must have developed its own explicit representation, that is, the text base, which consists in the identification and correlation of the explicit ideas or propositions that appear in the text by the use of their working memory (Graesser, 2007; Kintsch, 1988, 1998; Vieiro Iglesias \& Gómez Veiga, 2004). It consists on an interconnected network that comprises all the explicit propositions that appear on the text, that is, exact words and phrases, paraphrases, and local inferences, that allow the reader to tie the different parts of the text in a coherent and cohesive way. This type of knowledge is useful when the reader needs to look out for specific and precise details of the information contained on the text as well as for connecting basic information and ideas (Kintsch, 1988; León et al., 2013).

Then, once the reader has understood the main ideas of the text and how these are related, it should focus on other abilities such as the elaboration of global inferences and the integration of their previous knowledge with the new information provided by the text as well as making the implicit representation of the text which is known as the mental model (Cain et al., 2004; Kintsch, 1998; Vieiro Iglesias \& Gómez Veiga,
2004). The reader needs to make a series of inferences that connect the information explicitly stated on it with their previous knowledge about the world, the context and the text genre. It is important to bring out that some inferences are harder to make than others, and some of them require the integration of previous knowledge about the world.

In short, the reader combines both implicit and explicit information to create their own text base and mental model of the text, connecting the information that appears on a text level with their previous information and making the adequate inferences. However, creating a mental model of a text is no easy task and readers usually have trouble answering questions that requires them to activate their previous knowledge compared to more explicit questions about the text (Adams et al., 1995).

As such, reading comprehension is especially relevant during primary school years not only because during this period, children acquire and develop a series of abilities that are essential to this activity, but also because the child has to extract meaning from more and more complex texts, whose level increases with grade, in order to acquire new knowledge and meet the criteria of the curriculum (Kintsch 1998).

When analyzing reading comprehension in children, the majority of studies focused on the results obtained in the two most analyzed text genres: narrative and expository (Jeong, 2017; León et al., 2019; Míguez \& Cuevas, 2021). Although their definitions vary depending on the researcher, the narrative texts aim is to inform and describe a series of facts and actions that take place throughout a period of time (León et al., 2019). They usually contain simple language, reoccurring topics that happen in a particular setting and time involving concrete characters, and a series of events that are casually connected (McNamara et al., 2011 ; Sandford \& Emmott, 2012). On the other hand, expository texts are complex texts whose aim is to show the causally relationships that take place between facts and events (León et al., 2019). In comparison with narrative texts, these usually contain new and 
abstract concepts, a more complex relationship between words and sentences as well as a higher informational density (Bråten \& Anmarkrud, 2011 ; Coté et al., 1998; Meyer \& Ray, 2011).

Each type of text has a series of characteristics that the reader must recognize and, according to their experience with said genre, be able to activate all the information and strategies needed to understand it (Cueto, 2002). This could affect performance, especially when accounting for age: children in primary school understand narrative texts better because they are exposed to them since an early age, their vocabulary is similar to the words used on a daily basis, their syntactic structure is simple, they contain a series of events that are related, and the previous knowledge children possess is usually enough to understand them (Williams et al., 2005). On the other hand, expository texts are more unfamiliar due to the low exposure to this type, the logical and abstract relations that connect the ideas, the combination of different types structures (such as cause and effect, comparison and contrast, problem and solution and sequence and description), a more abstract and complex vocabulary as well as the introduction of less common cultural conventions (Kamberelis \& Bovino, 1999; Williams et al., 2005).

It has been proved that primary school students, both in English and Spanish, understand better narrative texts compared to expository ones (Best et al., 2008; Castillo \& Jiménez, 2016; Liebfreund \& Conradi, 2016; McNamara et al., 2011), including struggling readers (Williams et al., 2005). In fact, during the early grades of primary school, texts are mainly narrative and focus on technical aspects such as decoding words (phoneme-grapheme correspondences) and understanding simple syntax. From grade 4th onwards, texts become increasingly more difficult and expository texts become the main source of knowledge from which children will have to extract and learn new information (Duke, 2003). On the other hand, achieving a full mental model of a text is a difficult task and readers usually have less trouble extracting explicit information to form the text base than creating its mental model (Adams et al., 1995; Bowyer-Crane \& Snowling,
2005; Catts et al., 2006; De Mier et al., 2013; Perfetti \& Stafura, 2015).

Only a handful of studies have analyzed the correlation that exists between text genre and level of representation, none of which was conducted on a Spanish-speaking language sample. Of the few, Ohtsuka (1993) studied to what extent text genres influence the characteristics of mental models in narrative, expository and descriptive texts in a sample of undergraduate students. Their finding showed similar results between the first two genres but the authors focused their research on the consistency or inconsistency of the questions posited. More recently, Mcnamara et al. (2011) found that fourth grades needed more cohesion and background information in expository texts compared to narrative ones, which shows that, when reading a narrative text, readers had more knowledge available to facilitate comprehension.

Therefore, the purpose of this study is to understand the relationship that exists between text genre and level of representation (text base or mental model) in a sample of Spanish primary children, and analyses the differences between grades. Following the previously stated empirical framework, we hypothesize that students will obtain higher scores on narrative texts when compared to the results obtained on expository ones. This difference should be higher in 4th grade than in 6th grade due to a higher exposition to different types of texts in later grades as well as an improvement in reading abilities, expertise and inferencemaking (Barnes et al., 1996; Currie \& Cain, 2015; Lynch et al., 2008). In addition, since in order to create their text base the students only have to look for the proper answer on the text, which greatly simplifies the reading process, we assume that students will obtain higher scores in the text base variable compared to the mental model variable. Finally, we also hypothesized that the scores of the mental model would depend on both knowledge and experience with different text genres. Specifically, we predicted an advantage for higher scores in the text base and mental model when the texts were relatively familiar (i.e., narrative text) regardless of grade. 


\section{METHOD}

\section{-PARTICIPANTS}

The sample was comprised of 313 children (166 girls and 147 boys) who were randomly selected from three Spanish public schools from the province of Pontevedra. All of the participants had parental consent and agreed to participate in the study. The sample was divided into three groups according to their grade. The sample from $4^{\text {th }}$ grade included a total of 128 participants whose sample ranged from 8 to 10 years $(M=8.98, S D=0.4413), 5^{\text {th }}$ grade was comprised of 77 participants whose sample ranged from 9 to 11 years $(M=9.98, S D=$ 0.48 ) and 6th grade was comprised of 105 participants whose sample ranged from 10 to 13 years $(M=11.08, S D=0.50)$. According to the reports made by the teachers of the sample, although the whole class performed the task, we decided to exclude all the children with learning disabilities (in our case, one children from $5^{\text {th }}$ grade and two from $6^{\text {th }}$ grade from our original sample of 313 participants). As we saw afterwards in the results sheet, the three participants excluded were not able to perform the whole task in the allotted time and one of them had to quit the exercise because it was too taxing.

\section{-RESEARCH DESIGN}

The present research describes the results obtained through both descriptive and inferential analysis. The latter analysis consists of the use of a series of correlational methods, such as Pearson's $r$, to measure the degree of correlation between each variable, as well as an ANOVA analysis that will help us determine whether the performance analyzed was significant or not.

\section{- INSTRUMENTS}

Reading Comprehension Measures. For this research, we used the ECOMPLEC-Pri Test, Evaluation of Reading Comprehension for Primary School Students (León et al., 2011) an instrument that measures the scores obtained by primary school children in two types of texts: narrative and expository. The characteristics of the texts are as follows.

A narrative text titled El hombrecillo sabelotodo 'The Little Know-it-all', which consisted of 514 words and followed a dialogue format within a narrative structure. This text contained 22 reading comprehension questions of which 11 were questions about the explicit information that appeared on the text (text base) and 11 were specifically made for the creation of the mental model.

An expository text named Los glóbulos rojos 'Red Blood Cells', consisting of 348 words divided into 2 paragraphs that followed an academic text structure similar to those found in textbooks with a large number of concepts and technical terms adapted to the age of the participants. The text contained 21 reading comprehension questions of which 10 were related the text base and 11 formed the mental model.

As a control measure, we decided to use the Text Comprehension task of the PROLEC-R Battery (Cuetos et al., 2014). This consisted in two narrative and expository texts that the children had to read out-loud individually and, after reading each one, answer a series of questions posed by the examiner. According to the manual, since the children will not be able to look at the texts when answering the questions, and to avoid memorization, all of the questions were inferential and corresponded to the elaboration of the mental model. We used this measure to make sure that the results obtained on the first test were similar to the scores obtained in this task and, therefore, it represented our sample accurately.

Reading Comprehension Measures. To ensure that performance on the tasks was not solely driven by large variability in children's reading skills across grades, we accounted for two reading abilities using two tasks in the PROLEC- $R$ battery: Word reading and Pseudoword reading. For the first task, children had to read 40 real Spanish words that accounted for the majority of the words children normally use. For the second 
task, children had to read 40 pseudowords, that is, strings of letter that are orthographically correct and pronounceable but without meaning. In both tasks the number of errors committed when reading and the total word reading time was measured.

\section{-PROCEDURE}

The ECOMPLEC-Pri battery took place in the regular classroom under the supervision of the main teacher and the examiners. In order to achieve the desired results, we followed the standards that appear in the manual. First, the examiners introduced themselves to the students. Then, they reduced the anxiety of the group through a series of short questions about school, subjects and hobbies, always clarifying that the activity will not have any repercussion on their grades. Following this introduction, the examiners gave the participants the answer sheet and, together, they filled in the personal data that appears at the top of the paper. Next, the examiners gave them the booklet that contained the texts and the questions and they explained the responsive procedure, highlighting that they are not allowed to write on the booklet. After reading the instructions that appear on the first page, the examiners showed them how to mark on their answers on the sheet, by selecting one of the three possible answers ( $A, B$ or $C$ ) of each question as they deem appropriate. Subsequently, they reminded the students that, although this is not an exam, they should read the texts and answer the questions at their own pace, do their very best and ask any questions related to the procedure.

Afterwards, in a separate classroom that followed all the conditions stated on the manual of the battery, including no distractions, good lightning and temperature and adequate amenities, we performed the Text Comprehension task of the PROLEC-R Battery. To do so, we showed the children four texts (two narratives and two expositories) of different lengths about unknown topics. Each participant had to read aloud every text and, after finishing each one, answer four questions regarding the context of the text. The children were not able to pose any questions about the content of the text and, when the answer was too generic or simple, the examiner will ask them to elaborate more on the topic. If the answer was appropriate, they will receive one point, if not, zero points. The maximum amount of points that a student can receive is 16. After that, we performed the two reading tasks previously mentioned.

We corrected and marked the first battery using the TEACorrige software, a program provided by the manual of the battery ECOMPLEC-Pri. After inserting the data, this software automatically scores the answers using a series of algorithms and it gives us a sheet that contains a series of variables related to the score obtained in the narrative and expository texts, the global an and individual scores of the text base and the mental model of both genres. The PROLEC-R battery was scored manually following the standards that appear on the manual.

\section{RESULTS}

\section{- DATA VARIABLES}

As established before, the sample was divided according to their grade (4th, 5th or 6th). The TEA Corrige software gave us a total of eight variables (see Tables 1 to 3): the narrative text, the expository text, the text base (for both texts), the mental model (for both texts), the text base of the narrative text, the mental model of the narrative text, the text base of the expository text and the mental model of the expository text.

\section{-DATA ANALYSIS}

Taking into account the correspondence table that appears on the manual of the battery (Table 4), we can establish that the mean of all the groups analyzed was located among the medium qualitative rank and, therefore, the majority of students performed well on both texts (see Tables 1-3). The medium rank results obtained on the PROLEC-R Battery were also in line to the results obtained in the ECOMPLEC-Pri in each grade, and thus, we can confirm that the results obtained in our tests were adequate for our sample and not simply due to chance. 
Table 1

Descriptive Analysis ECOMPLEC-PRI (4th grade) $^{\text {th }}$

\begin{tabular}{|c|c|c|c|c|c|}
\hline & N & Min. & Max. & M & SD \\
\hline General Comprehension & 128 & 4 & 97 & 44.45 & 16.36 \\
\hline Narrative Text & 128 & 4 & 83 & 50.60 & 16.362 \\
\hline Expository Text & 128 & 9 & 76 & 45.29 & 15.71 \\
\hline Mental Model & 128 & 3 & 97 & 45.38 & 16.394 \\
\hline Mental Model (Narrative) & 128 & 1 & 88 & 50.59 & 17.43 \\
\hline Mental Model (Expository) & 128 & 3 & 76 & 47.10 & 14.70 \\
\hline Text Base & 128 & 4 & 77 & 44.30 & 17.05 \\
\hline Text Base (Narrative) & 128 & 9 & 88 & 51.16 & 16.86 \\
\hline Text Base (Expository) & 128 & 4 & 80 & 43.83 & 18.38 \\
\hline
\end{tabular}

Table 2

Descriptive Analysis ECOMPLEC-PRI ( $5^{\text {th }}$ grade)

\begin{tabular}{|c|c|c|c|c|c|}
\hline & $N$ & Min. & Max. & M & SD \\
\hline General Comprehension & 77 & 4 & 97 & 53.82 & 20.22 \\
\hline Narrative Text & 77 & 3 & 97 & 56.44 & 19.31 \\
\hline Expository Text & 77 & 9 & 97 & 55.68 & 17.22 \\
\hline Mental Model & 77 & 4 & 97 & 52.84 & 20.94 \\
\hline Mental Model (Narrative) & 77 & 3 & 88 & 55.12 & 18.95 \\
\hline Mental Model (Expository) & 77 & 4 & 88 & 54.13 & 18.40 \\
\hline Text Base & 77 & 3 & 97 & 53.75 & 20.38 \\
\hline Text Base (Narrative) & 77 & 17 & 88 & 57.18 & 17.98 \\
\hline Text Base (Expository) & 77 & 9 & 97 & 54.95 & 18.04 \\
\hline
\end{tabular}

Table 3

Descriptive Analysis ECOMPLEC-PRI (6 $6^{\text {th }}$ grade)

\begin{tabular}{|c|c|c|c|c|c|}
\hline & $N$ & Min. & Max. & M & N \\
\hline General Comprehension & 105 & 3 & 97 & 51.49 & 20.26 \\
\hline Narrative Text & 105 & 9 & 85 & 52.11 & 18.43 \\
\hline Expository Text & 105 & 9 & 88 & 50.00 & 18.50 \\
\hline Mental Model & 105 & 3 & 97 & 51.50 & 19.45 \\
\hline Mental Model (Narrative) & 105 & 4 & 75 & 49.40 & 16.35 \\
\hline Mental Model (Expository) & 105 & 4 & 85 & 49.03 & 17.84 \\
\hline Text Base & 105 & 3 & 97 & 51.98 & 20.02 \\
\hline Text Base (Narrative) & 105 & 9 & 76 & 52.85 & 17.37 \\
\hline Text Base (Expository) & 105 & 4 & 83 & 51.07 & 18.25 \\
\hline
\end{tabular}




\section{Table 4}

Mean Scores and their Qualitative Rank

\begin{tabular}{|c|c|}
\hline Mean scores & Qualitative Rank \\
\hline $70-100$ & High \\
\hline $61-69$ & Medium High \\
\hline $40-60$ & Medium \\
\hline $31-39$ & Medium Low \\
\hline $0-30$ & Low \\
\hline
\end{tabular}

Table 5

Mean Scores and their Qualitative Rank

\begin{tabular}{|c|c|c|c|c|c|c|c|c|c|c|}
\hline & GC & NT & ET & MM & MMn & MMe & TB & $\mathrm{TBn}$ & TBe & $\mathrm{TC}$ \\
\hline \multicolumn{11}{|l|}{ GC } \\
\hline NT & $.798 * \star \star$ & & & & & & & & & \\
\hline ET & $.805^{\star \star \star}$ & $.497 * * *$ & & & & & & & & \\
\hline $\mathrm{MM}$ & $.927^{\star \star}$ & $.730 * \star$ & 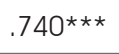 & & & & & & & \\
\hline MMn & $.731^{\star \star *}$ & $.870 * *$ & $.475^{\star \star}$ & $.780 * \star \star$ & & & & & & \\
\hline MMe & $.683^{\star \star \star}$ & $.419 * \star$ & $.829 \star \star$ & $.763^{\star \star}$ & $.438^{\star \star \star}$ & & & & & \\
\hline $\mathrm{TB}$ & $.920 * \star$ & $.755^{\star \star}$ & $.779 * \star$ & $.731 * \star$ & $.588^{\star \star}$ & $.524^{\star \star *}$ & & & & \\
\hline TBn & $.706^{\star \star \star}$ & $.878^{* \star}$ & $.434^{\star \star}$ & $.546^{\star \star}$ & $.566^{\star \star}$ & $.328^{\star \star \star}$ & $.765^{\star \star \star}$ & & & \\
\hline $\mathrm{TBe}$ & $.704^{\star * \star}$ & $.447^{\star *}$ & $.862^{\star \star}$ & $.538 * \star$ & $.396^{\star \star}$ & $.465^{\star \star *}$ & .796 ** & $.410 * * *$ & & \\
\hline TC & $.425^{\star \star \star}$ & $.404^{\star *}$ & $.368^{\star *}$ & $.406 * \star$ & $.363^{* \star}$ & $.342^{\star *}$ & $.400 * *$ & $.342 \star \star$ & $.303^{* * *}$ & \\
\hline
\end{tabular}

Note. $\mathrm{GC}=$ General Comprehension, NT = Narrative Text, EP= Expository Text, MM = Mental Model, MMn = Mental Model (Narrative), $M M e=$ Mental Model (Expository), TB = Text Base, TBn = Text Base (Narrative), TBe $=$ Text Base (Expository), $\mathrm{TC}=$ Text Comprehension (PROLEC-R); ${ }^{* * *} p<.001$.

As we saw before, the participants from all grades performed slightly better on the narrative text compared to the expository one. However, there were a few minor differences between grades regarding the question type analyzed. Children from 4th grade obtained better results on the text base of the narrative and expository texts compared to their mental model (51.16 and 47.10 vs. 50.59 and 43.83, respectively). On the other hand, students from 5th grade obtained a higher score on the text base of the narrative text (57.18 compared to 55.12 on the mental model of the narrative) while the scores for both the text base and the mental model of the expository text were almost the same (54.95 and 54.13 , respectively). Finally, the participants from 6th grade obtained higher scores on the text base of both the narrative and expository texts (52.85 and 51.07vs. 49.40 and 49.03).
Regarding the inferential analysis, first, we examined the degree of correlation between each variable using Pearson's r. As table 5 shows us, all the variables were heavily correlated with each other ( $p=<.01)$, as well as with the reading comprehension task of the PROLEC-R battery.

In this work we are considering both the correlation between the variables in tables 1, 2 and 3 and the association between them and the grade. They are not considered independent since in the final part of the manuscript all the variables are related and coherent conclusions are drawn between them.

To determine whether the performance analyzed on the descriptive analysis was significant and, therefore, if our sample obtained 
a differential performance depending on the type of text and level of representation, we grouped the results in a cluster dendrogram in which the height of the dendrogram represents the distance between clusters according to their degree of association (those closer to 0 have a higher value of association than the ones closer to 1). This analysis can help us select the variables so that they do not provide redundant information to the analysis of variance. The authors have considered a one-way ANOVA where the factor (Grade) has three levels: 4th, 5th, 6th. This last model allows us to study in more depth each of the variables that characterize reading comprehension. As Figure 1 shows, if we set as a cut-off point a middle value such as .6, we can analyses the differences between the five groups highlighted in squares.

After the variables were selected, we proceed to calculate the Spearman association coefficient, $\rho$, between these variables and grade. A significant association was found, $\rho=.63$, $p<.05$, between the reading comprehension scores and the grade of the participants. There is also a significant relationship between the results obtained in both texts, $\rho=.48, p<.001$, as well as within the mental model and the text base of each text: expository, $\rho=.47 ; p<.001$ and narrative, $\rho=.57, p<.001$.
Furthermore there is a significant relationship between the variable 'grade' and the variables 'expository text' (between grades 4th and 5th), the text base of the expository text (between grades 4th and 5th), 'general comprehension', 'mental model' and 'text base'. In addition, the association between the mental model and the text base of each text is significant for all grades: narrative text, $\rho=.57, p<$ .001 , and expository text, $\rho=.47, p<.001$. A more detailed study shows that this degree of association increases with grade. Thus, when working with a narrative text, the association between the mental model and the text base increases from .45 in 4th grade to .66 in 6 th grade. On the other hand, when working with an expository text, a more moderate increase has been observed, since it increased from .44 in 4th grade to .50 in 6 th grade.

The results (see Table 6) showed significant differences in General Reading Comprehension mediated by the grade factor. The post hoc analysis (Bonferroni correction: .05/3 =.017) established a lower general reading comprehension in $4^{\text {th }}$ grade $(M=44.45)$ compared to $5^{\text {th }}(M$ $=53.83)$ and 6 th grade $(M=51.49)$. These differences in general comprehension are limited to expository texts (in narrative texts there are no differences for the grade factor), such that 4th

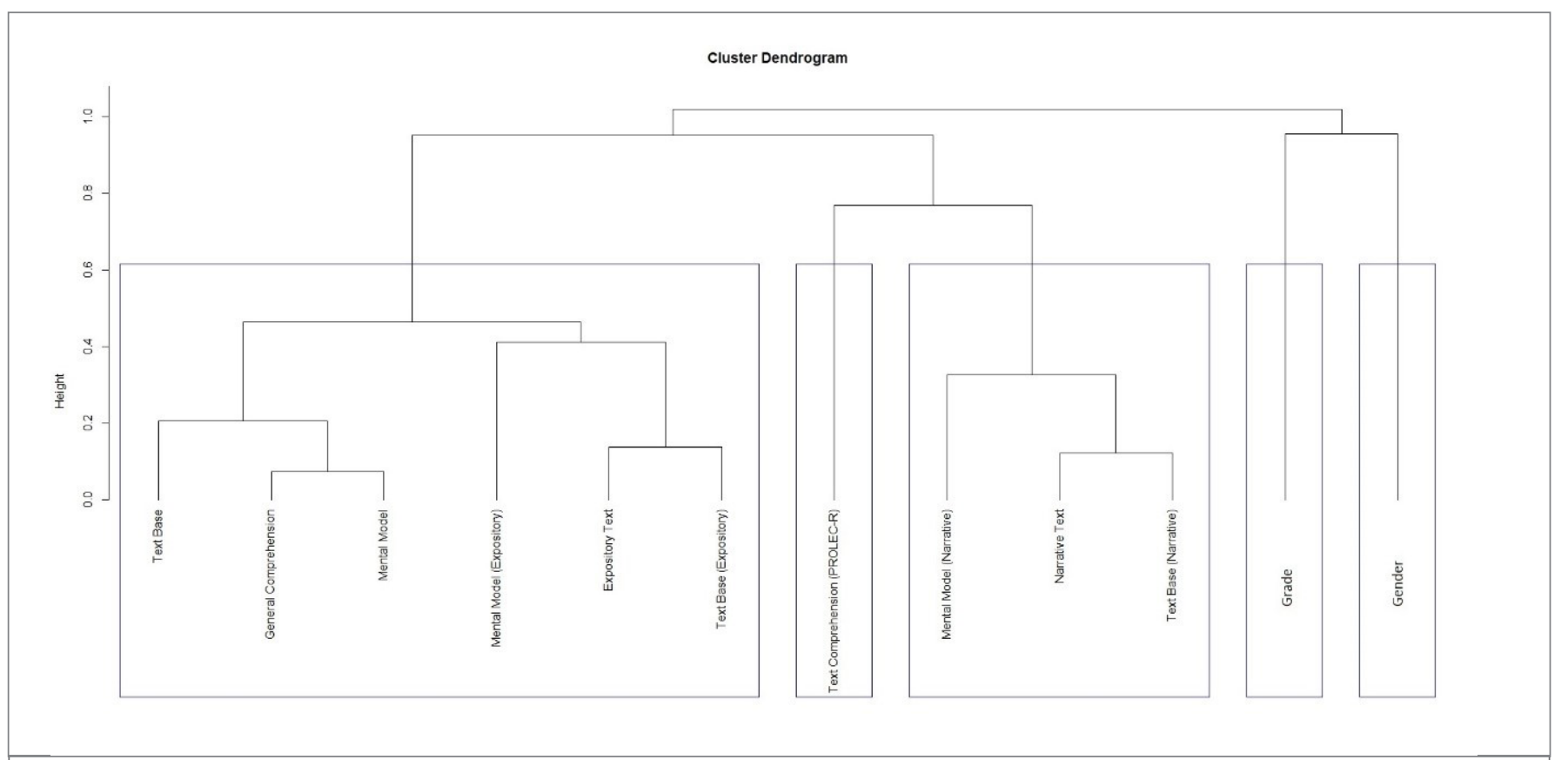

Figure 1. Cluster dendrogram of the variables 
graders $(M=45.29)$ show lower comprehension in expository texts than $5^{\text {th }}$ graders $(M=55.68)$. In relation to the mental model, it was found that the grade factor leads to significant differences. Post hoc analysis (Dunnett's C) reported a lower score in $4^{\text {th }}$ grade $(M=45.38)$ than in 5 th grade $(M=52.84)$. Again, it is in the expository text where differences in the mental model were manifested (in the narrative text no differences were observed in the mental model) (see Table 6) and the post hoc analysis (Dunnett's C) referred to significantly lower scores in 4 th grade $(M=$ 47.10) than in $5^{\text {th }}$ grade $(M=54.13)$. Lastly, significant differences were found in text base for the grade factor (see Table 6) that the post hoc analysis (Bonferroni correction: .05/3 = $.017)$ concretized in significant lower scores in $4^{\text {th }}$ grade $(M=44.30)$ in comparison with $5^{\text {th }}$ $(M=53.75)$ and 6th grade $(M=51.98)$. Once again, differences were only in the expository text (see Table 6), not for the narrative text, and the post hoc analysis (Bonferroni correction: .05/3 = $.017)$ shows significant lower scores in 4th grade $(M=43.83)$ in contrast to 5 th $(M=54.95)$ and $6^{\text {th }}$ grade $(M=51.07)$.
Finally, to ensure that performance on the tasks was not solely driven by large variability in children's reading skills across grades, we accounted for results in word reading and pseudoword reading (using the tasks that appear in the PROLEC-R battery as stated before). The results of the one-way ANOVA for word reading were significant, $F(2,310)=26.04, p<.001$, $1-\beta=1$, explaining $14.6 \%$ of the variance, as well as for pseudoword reading, $F(2,310)$ $=45.51, p<.001,1-\beta=1$, accounting for $22.7 \%$ of the variance, $\eta_{p}^{2}=.227$. Post hoc analysis (Bonferroni correction: .05/3 =.017) stated for word reading significant lower scores in $4^{\text {th }}(M=130.75)$ degree than in 6th degree $(M=141.12)$; meanwhile that for pseudoword reading significant lower scores were registered in $4^{\text {th }}$ degree $(M=55.43)$ in comparison with $5^{\text {th }}(M=64.26)$ and 6 th degree $(M=79.27)$. These results show that reading skills improved with grade, developing as expected, and did not act as a confound in this research.

Table 6

Mean comparisons (ANOVA) for the grade factor on the evaluation of reading comprehension measures.

\begin{tabular}{|c|c|c|c|}
\hline Variable & $F$ & $\rho$ & $\eta_{p}^{2}$ \\
\hline General Comprehension & 7.29 & .001 & .045 \\
\hline Narrative Text & 2.64 & .073 & .017 \\
\hline Expository Text & 9.34 & .000 & .057 \\
\hline Mental Model & 4.53 & .011 & .028 \\
\hline Mental Model (Narrative) & 2.60 & .076 & .016 \\
\hline Mental Model (Expository) & 4.32 & .014 & .770 \\
\hline Text Base & 7.64 & .001 & .516 \\
\hline
\end{tabular}




\section{DISCUSSION}

The purpose of this study was to examine children's reading comprehension scores in narrative and expository texts and their relationship with the creation of the text base and the mental model of each text, as well as to account for differences between grades. Specifically, we predicted an advantage for higher scores in the text base and mental model when the texts were relatively familiar (i.e., narrative text) regardless of the grade of the participant. In the following sections we will analyze each variable individually.

\section{-TEXTGENREAND READING COMPREHENSION}

Primary school children usually obtain better scores on narrative texts in comparison to expository texts, due to a higher exposure from early ages as well as a simpler structure and vocabulary of said texts (Best et al., 2008; Castillo \& Jiménez, 2016; Duke, 2000; Kamberelis \& Bovino, 1999; Liebfreund \& Conradi, 2016; Mcnamara et al., 2011 ; Williams et al., 2005). These results are usually affected by age and grade due to an increment in the exposure to expository texts as well as an improvement in reading abilities, expertise and inference making in later grades (Barnes et al., 1996; Currie \& Cain, 2015; Lynch et al., 2008). Thus, this article aimed at identifying the differences in the results obtained in the narrative and expository texts as well as the differences between the level of representation for each genre while taking into account the grade of the participants to see if these were significant or not.

Our results show that, in line with previous research, the participants of every grade obtained higher scores in the narrative text compared to the expository one (Best et al., 2008; Castillo \& Jiménez, 2016; Liebfreund \& Conradi, 2016; Mcnamara et al., 2011), a difference quite large that explains $22.5 \%$ of the variance. However, as texts from grade 4th onwards become increasingly more difficult and students have to extract new contents from plenty of expository texts that became the main source of information (Duke, 2003; León et al., 2019) we can establish that students with time and practice gained more expertise and, as our sample shows, their results improved and the differences between the expository text diminished. In fact, the one-way ANOVA showed that there are not significant differences between grades in the scores obtained in the narrative text, which implies that the results were homogeneous between 4 th and 6th grades (no significant improvement was noticed) while in the case of the expository text, scores on 5th grade were significantly higher than scores on 4 th grade that shows a clear improvement in reading comprehension. It is also noteworthy the fact that the results between 5th and 6th grade were not especially different, which implies that 5th graders reached a ceiling in their performance on expository texts, that is, by that age they developed all the abilities necessary to create a proper mental model of said text.

\section{- LEVEL OF REPRESENTATION AND READING COMPREHENSION}

In addition, the information that any text provides can be explicit, that is, the direct interpretation of the exact words, phrases, sentences and paraphrases that are interconnected in the text and contain its ideas and information, which creates the text base representation (Kintsch, 1988; Cuetos et al., 2014); or implicit, that is, the creation of global inferences that connect the information that appears in the text with the previous knowledge of the reader creating their mental model (Oakhill \& Cain, 2007; Ramírez, 2015; Tumner \& Bowey, 1984). However, it is easier to understand only the text base of a text compared to creating its complete mental representation. That means that participants have more trouble answering implicit questions that involve the creation of complex relationships between different parts of the text and activate previous knowledge, compared to more explicit ones (Adams et al., 1995; Bowyer-Crane, 2005; Catts et al., 2006; De Mier et al., 2013; Florit et al., 2001; Perfetti \& Stafura, 2015). This expertise usually changes and develops with time and experience, which means that we should expect different results depending on the grade of the participant. 
In our case, the association between the mental model and the text base of each text was significant, which implies that all grades obtained significant higher scores on the text base than the mental model explaining $32.5 \%$ of the narrative text variance, and $21.9 \%$ of the expository text variance. Similar to the results presented previously, fourth graders obtained significantly lower results (both in the mental model and the text base) compared to 5th and 6th graders but only in the expository texts (in the narrative texts no differences were observed due to its familiarity). This means that students improve in the creation of their text base and mental model of the expository texts with time and experience from 4th grade to 5 th and 6 th grade, while in 4 th grade they have already reached their ceiling of performance in the narrative genre.

\section{- LEVEL OF REPRESENTATION AND TEXT GENRE}

Due to the higher familiarity primary schoolers have with narrative texts, we hypothesized that the scores of both the text base and the mental model will be higher in this text genre compared to the expository text. Although the descriptive analysis show that this was true for the three grades (see Tables 1, 2 and 3), that is, students tend to obtain higher scores in the creation of the text base and the mental model when the text is narrative, the inferential analysis showed no significant differences between these variables and, thus, we can state that the results obtained in the creation of the level of representation are not influenced by text genre.

\section{- IMPLICATIONS FOR EDUCATION}

Our study provides a series of important insights for future education in reading comprehension. First, it appears that it is important for fourth graders the difference between explicit and implicit information when answering reading comprehension questions. Second, due to the difficulty in the development of a mental model of any type of text and a limited exposure to expository texts during the early stages of childhood, the creation of the mental model of expository texts can be particularly challenging (compared to the creation of its text base).
Therefore, on the basis of the results obtained in this paper, and also related to other studies discussed throughout this article, we suggest to apply a series of measures both in the regular classroom as well as when performing a reading comprehension test.

We propose to include in the classroom since early grades different types of reading activities and exercises, paying specific attention to all kinds of expository texts. We also encourage applying an intervention program that proposes a series of activities that will help students differentiate between narrative and expository texts as well as give them a series of strategies to help them improve their reading comprehension in both types of texts. It is noteworthy the programs proposed by Hall et al. (2007) and Cunha and Capellini (2017), as well as those included in the review made by Meyer and Ray (2011), about strategies that students can implement when reading expository texts. Furthermore, we also encourage teachers to ask different types of questions when reading a text (both explicit and implicit) in order to help students to fully understand the text they are reading and to help them implement different strategies that will allow them to incorporate their previous knowledge to the information contained in the text with the objective of building their mental model.

In addition, it is known that, if teachers want to properly assess the reading comprehension ability of their students and their performance, they should use reading comprehension tests that are reliable and are related to the curriculum that is being implemented in the classroom. However, due to the diversity of tests and batteries that we can find on the market, it can be difficult to obtain reliable scores, especially when we compare the scores obtained on two or more tests (Hua \& Keenan, 2017; Reed \& Vaughn, 2012). We believe that these problems can be avoided if the take into account that reading comprehension changes depending on the age and grade of the participants and their previous experience with different types of textual genres (which, as seen before, changes over time). Thus, the tests used should account for these differences and use different scales and/or algorithms that are age 
or grade-dependent when measuring the results obtained or use a specific test that is specifically targeted to the sample analyzed (Betjemann et al., 2011 ; Lonigan \& Burgess, 2017; Keenan et al., 2008; Snow, 2003).

\section{- LIMITATIONS}

This study has some limitations. First, we excluded from our sample all the children with disabilities (three children in our case). We did so because we wanted to give all the students the same amount of time to read the texts and answer the questions, which was clearly not enough for the three participants who did not answer the minimum amount of questions for the software to analyze. In fact, when entering the data of these participants into the program, it gave us a null score. In future research we think it would be interesting to include children with disabilities into the data and analyze their differences with the average group.

Second, although we used a control test to account for the results obtained in the main one, this study is limited because we included data from just one narrative text and one expository text. In future research, we will include more texts of different formats that will overcome the influence that could have had an impact on our results such as familiarity with the topic and structure of the texts.

Finally, since reading comprehension comprises many abilities besides the creation of a text base or mental model, our aim in a future paper is to compare the results obtained in this research with the scores obtained in other types of tasks such as decoding, recognition of syntactic structures and oral comprehension.

\section{CONCLUSIONS}

This article has analyzed the influences of text genre and level of representation in reading comprehension in Spanish in a sample of Spanish primary school children. Our results show that scores in the narrative text are higher than in the expository one regardless of grade, and that students obtained lower general reading comprehension scores in $4^{\text {th }}$ grade compared to $5^{\text {th }}$ and $6^{\text {th }}$ grade but only on the expository text (in the narrative text there are no differences for the grade factor). In addition, regarding the level of representation analyzed, all grades obtained significant higher scores on the text base than the mental model of each text but students improved in the creation of their text base and mental model of the expository texts with time and experience when passing from $4^{\text {th }}$ to $5^{\text {th }}$ and $6^{\text {th }}$ grade. This result implies that, as the exposure to expository texts from grade 4th onwards increases and the demands on reading comprehension are higher, students gain more expertise and, therefore, their reading abilities improve.

We believe that this study presents new insights to improve reading comprehension such as focusing since early ages not only on different types of text and their characteristics but also on the different strategies needed to help build their mental model, especially when reading expository texts.

\section{- Conflict of interest}

No potential competing interest was reported by the authors.

Data availability statement: The data that support the findings of this study are available on request from the corresponding author. The data are not publicly available due to privacy restrictions.

\section{REFERENCES}

Adams, B. C., Bell, L. C., \& Perfetti, C. (1995). A trading relationship between reading skills and domain knowledge in children's text comprehension. Discourse Processes, 20, 307-323. https://doi. org/10.1080/01638539509544943

Barnes, M. A., Dennis, M., \& HaefeleKalvaitis, J. (1996). The effects of knowledge availability and knowledge accessibility on coherence and elaborative inferencing in children from six to fifteen years of age. Journal of Experimental Child Psychology, 61, 216-241. https://doi.org/10.1006/ jecp.1996.0015 
Bråten, I., \& Anmarkrud, Ø. (2011). Does naturally occurring comprehension strategies instruction make a difference when students read expository text? Journal of Research in Reading, 36(1), 42-57. https://doi. org/10.1111/i.1467-9817.2011.01489.x

Best, R., Ozuru, Y., Floyd, R., \& Mcnamara, D. S. (2008). Differential competencies contributing to children's comprehension of narrative and expository texts. Reading Psychology, 29(2), 137-164. https://doi. org/10.1080/02702710801963951

Betjemann, R. S., Keenan, K., Olson, R. K., \& DeFries, J. C. (2011). Choice of reading comprehension test influences the outcomes of genetic analyses. Scientific Studies of Reading, 15(4), 363-382. https://doi.org/ 10.1080/10888438.2010.493965

Bowyer-Crane, C., \& Snowling, M. J. (2005). Assessing children's inference generation: what do tests of reading comprehension measure? British Journal of Educational Psychology, 75(2), 189-201. https://doi. org/10.1348/000709904X22674

Brockmeier, J., \& Olson, D. R. (2009). The Literacy Episteme: From Innis to Derrida. In D. Olson \& N. Torrance (Eds.), The Cambridge book of literacy (pp. 3-22). Cambridge, UK: Cambridge University Press.

Cain, K., Oakhill, J., \& Lemmon, K. (2004). Individual differences in the inference of word meanings from context: The influence of reading comprehension, vocabulary knowledge and memory capacity. Journal of Educational Psychology, 96(4), 671681 . https://doi.org/10.1037/00220663.96 .4 .671

Castillo, A. V., \& Jiménez, G. (2016). ¿̇s adecuado el enfoque de los libros de texto para el desarrollo de la comprensión lectora?: Análisis crítico de materiales de Educación Primaria [ls it appropriate the approach of textbook for the development of reading comprehension?: Critical analysis of primary Education materials]. Opción, 32, 437-454. Retrieved from https://www. redalyc.org/pdf/310/31048480024.pdf
Catts, H. W., Adlof, S. M., \& Weismer, S. E. (2006). Language deficits in poor comprehenders: A case for the simple view of reading. Journal of Speech Language and Hearing Research, 49 (2), 278-293. https:// doi.org/10.1044/1092-4388(2006/023)

Coté, N., Goldman, S. R., \& Saul, E. U. (1998). Students making sense of informational text: Relations between processing and representation. Discourse Processes, 25(1), 1-53. https://doi.org/10.1093/ her/12.3.385

Cueto, N. (2002). Representación e inferencia. El proceso de la interpretación. Oviedo, Spain: Department of Spanish Philology, University of Oviedo.

Cuetos, F., Rodríguez, B., Ruano, E., \& Arribas, D. (2014). PROLEC-R. Batería de Evaluación de los Procesos Lectores, Revisada. Madrid, Spain: TEA Ediciones.

Cunha, V. L., \& Capellini, S. A. (2017). Informative intervention programs to reading comprehension: Development and implementation. Estudos de Psicologia (Campinas), 34(3), 411-422. https://doi. org/10.1590/1982-02752017000300009

Currie, N. K., \& Cain, K. (2015). Children's inference generation: The role of vocabulary and working memory. Journal of Experimental Child Psychology, 137, 57-75. https://doi. org/10.1016/i.jecp.2015.03.005

De Mier, M. V., Borzone, A. M., Sánchez Abchi, V. S., \& Benítez, M. E. (2013). Habilidades de comprensión y factores textuales en los primeros grados. Revista Peruana de Psicología y Trabajo Social, 2(1), 89-106. Retrieved from https://core.ac.uk/download/ pdf/52476603.pdf

Duke, N. K. (2000). 3.6 minutes per day: The scarcity of informational texts in first grade. Reading Research Quarterly, 35(2), 202224. https://doi.org/10.1598/RRQ.35.2.1

Duke, N. K. (2003). Reading to learn from the very beginning: Information books in early childhood. Young Children, 58(2), 14-20.

Eloranta, A., Närhi, V., Ahonen, T., \& Tuija, A. (2019). Does childhood reading disability or its continuance into adulthood underlie 
problems in adult-age psychosocial wellbeing? A follow-up study. Scientific Studies of Reading, 23(4), 273-286. https://doi.org $\angle 10.1080 / 10888438.2018 .1561698$.

Florit, E., Roch, M., \& Levorato, C. (2011). Listening text comprehension of explicit and implicit information in preschoolers: The role of verbal and inferential skills. Discourse Processes, 48(2), 119-138. https://doi. org/10.1080/0163853X.2010.494244

Graesser, A. C. (2007). An introduction to strategic reading comprehension. In D. S. McNamara (Ed.), Reading comprehension strategies. Theories, interventions and technologies (pp. 3-26). Mahwah, NJ: Lawrence Erlbaum Associates.

Hall, K. M., Sabey, B. L., \& McClellan, M. (2007). Expository text comprehension: Helping primary-grade teachers use expository texts to full advantage. Reading Psychology, 26(3), 211-234. https://doi. org/10.1080/02702710590962550

Hua, A. N., \& Keenan, J. M. (2017). Interpreting reading comprehension text results: Quantile regression shows that explanatory factors can vary with performance level. Scientific Studies of Reading, 21 (3), 225-238. https:// doi.org/10.1080/10888438.2017.12806 75

Jeong, H. (2017). Narrative and expository genre effects on students, raters and performance criteria. Assessing Writing, 31, 113-125. https://doi.org/10.1016/i. asw.2016.08.006

Kamberelis, G., \& Bovino, T. D. (1999). Cultural artifacts as scaffolds for genre development. Reading Research Quarterly, 34(2), 138 170. https://doi.org/10.1598/RRQ.34.2.2

Keenan, J. M., Betjemann, R. S., \& Olson, R. K. (2008). Reading comprehension texts vary in the skills they assess: Differential dependence of decoding and oral comprehension. Scientific Studies of Reading, 12(3), 281-300. https://doi. org/10.1080/10888430802132279

Kintsch, K. (1988). The role of knowledge in discourse comprehension: A ConstructionIntegration model. Psychological Review, 95,
163-182. https://doi.org/10.1016/s0166$4115(08) 61551-4$

Kintsch, W. (1998). Comprehension: A paradigm for cognition. Cambridge, UK: Cambridge University Press.

León, J. A., Escudero Domínguez, I., \& Olmos Albacete, R. (2012). ECOMPLEC. Evaluación de la comprensión lectora. Madrid, Spain: TEA.

León, J. A., Escudero, I., \& van den Broek, P. (2013). La influencia del género del texto en el establecimiento de inferencias. In J. A. León (Ed.), Conocimiento y discurso: Claves para inferir y comprender (pp. 153-170). Madrid, Spain: Pirámide.

León, J. A., Martínez-Huertas, J. A., Olmos, R., Moreno, J. D., \& Escudero, I. (2019). Metacomprehension skills depend on the type of texts: An analysis from Differential Item Functioning. Psicothema, 31(1), 66-72. https://doi.org/10.7334/ psicothema2018.163

Liebfreund, M. D., \& Conradi, K. (2016). Component skills affecting elementary students' informational text comprehension. Reading and Writing, 29, 1141-1160. https://doi.org/10.1007/s11145-0169629-9

Lonigan, C. J. (2007). Development, assessment, and promotion of preliteracy skills. Education and Development, 17(1), 91-114. https://doi.org/10.1207/ s15566935eed1701 5

Lonigan, C. J., \& Burgess, S. R. (2017). Dimensionality of reading skills with elementary school-age children. Scientific Studies of Reading, 21 (3), 239-253. https:// doi.org/10.1080/10888438.2017.12859 $\underline{18}$

Lynch, J. S., van den Broek, P., Kremer, K., Kendeou, P., White, M. J., \& Lorch, E. P. (2008). The development of narrative comprehension and its relation to other early reading skills. Reading Psychology, 29(4), 327-365. https://doi. org/10.1080/02702710802165416

McNamara, D. S., Ozuru, Y., \& Floyd, R. G. (2011). Comprehension challenges in the 
fourth grade: The roles of text cohesion, text genre, and readers' prior knowledge. International Electronic Journal of Elementary Education, 4(1), 229-258. Retrieved from https://www.iejee.com/index.php/IEJEE/ article/view/222/218

Meyer, B. J., \& Ray, M. N. (2011). Structure strategy interventions: Increasing reading comprehension of expository text. International Electronic Journal of Elementary Education, 4(1), 127-152. Retrieved from https://www.iejee.com/index.php/IEJEE/ article/view/217

Míguez, C., \& Cuevas, M. (2021) Tipología textual y comprensión lectora en el alumnado de educación primaria. En D. Caldevilla (Ed.), Libro de Actas del X Congreso Universitario Internacional sobre Contenidos, Investigación, Innovación y Docencia (p. 763) Madrid, Spain: Fórum Internacional de Comunicación y Relaciones Públicas.

Oakhill, J., \& Cain, K. (2007). Issues of causality in children's reading comprehension. In D. S. McNamara (Ed.), Reading comprehension strategies. Theories, interventions and technologies (pp. 47-71). Mahwah, NJ: Lawrence Erlbaum Associates.

Ohtsuka, K. (1993, November 23). Text genres and mental models: What readers get from text and how they use it [Conference presentation abstract]. Australian Association for Research in Education (AARE) Annual Conference, Fremantle, Western Australia. Retrieved from https://www.aare.edu.au/ publications/aare-conference-papers/ show/879/text-genres-and-mental-modelswhat-readers-get-from-text-and-how-they$\underline{\text { use-it }}$

Perfetti, C. A., \& Stafura, J. Z. (2015). Comprehending implicit meanings in text without making inferences. In E. J. O'Brien, A. E. Cook, \& R. F. Lorch Jr. (Eds.), Inferences during reading (pp. 1-18). Cambridge, UK: Cambridge University Press.
Ramírez, E. M. (2015). La lectura más allá de la letra en la formación de lectores. Investigación Bibliotecológica, 29, 7-14. https://doi. org/10.1016/i.ibbai.2016.02.023

Reed, D., \& Vaughn, S. (2012). Retell as an indicator of reading comprehension. Scientific Studies of Reading, 16(3), 187217. https://doi.org/10.1080/10888438.2 $\underline{010.538780}$

Sandford, A., \& Emmott, C. (2012). Mind, brain and narrative. Cambridge, UK: Cambridge University Press.

Snow, C. E. (2003). Assessment of reading comprehension. Researchers and practitioners helping themselves and each other. In A. P. Sweet \& C. E. Snow (Eds.), Rethinking reading comprehension (pp. 192206). New York, NY: The Guildford Press.

Tumner, W. E., \& Bowey, J. A. (1984). Metalinguistic awareness and reading acquisition. In W. E. Tumner, C. Pratt, \& M. L. Herriman (Eds.), Metalinguistic awareness in children. Theory, research and implications (pp. 144-168). Berlin, Germany: SpringerVerlag.

Vieiro Iglesias, P., \& Gómez Veiga, I. (2004). Psicología de la lectura. Madrid, Spain: Pearson Prentice Hall.

Williams, J. P., Hall, K. M., Laver, K. D., Stafford, K. B., De Sisto, L. A., \& deCani, J. S. (2005). Expository text comprehension in the primary grade classroom. Journal of Educational Psychology, 97(4), 538-550. https://doi. org/10.1037/0022-0663.97.4.538

Yildrim, K., Cetinkaya, F. C., Ates, S., Kaya, D., \& Rasinski, T. (2020). Testing the KAPS model of reading comprehension in a Turkish elementary school context from low socioeconomic background. Education Sciences, 10(4), 90-100. https://doi. org/10.3390/educsci10040090 